International Journal of Linguistics, Literature and Culture
Available online at https://sloap.org/journals/index.php/ijllc/
Vol. 5, No. 1, January 2019, pages: 12 23
ISSN: 2455-8028
https://doi.org/10.21744/ijllc.v5n1.461

\title{
Designing Bali Tourism Model through the Implementation of Tri Hita Karana and Sad Kertih Values
}

\author{
Ni Nyoman Sri Astuti a \\ Gede Ginaya ${ }^{b}$ \\ Ni Putu Wiwiek Ary Susyarini ${ }^{\mathrm{c}}$
}

Article history:

Received: 18 July 2018

Accepted: 30 November 2018

Published: 19 December 2018

\section{Keywords:}

community services;

local wisdom;

rural tourism;

sad kertih;

tri hita karana;

\begin{abstract}
As an icon of tourism in Indonesia, Bali has developed to be one of the worldtop tourist destinations. In 2017, Bali gained an award to be the world's best tourist destination by Trip Advisor, the world largest travel site. As a result, the award would also boost the government's endeavors to reach the target of 20 million foreign tourists by 2019. In fact, this award and a number of other awards that had been attributed to the island of God are achieved due to the unity of the movement of the implementation of Tri Hita Karana (THK) and Sad Kertih (SK) values as local wisdom in maintaining Balinese balance. This study aims at investigating the implementation of THK and SK values in designing Bali tourism model in the context of community services of Indonesian higher education. By applying the descriptive qualitative research method, the data, both primary and secondary, were collected through participant observation in 7 seven villages of different regency in Bali Province, interview, and literature study. The study found, so far, the implementation of THK and SK values in designing Bali tourism model has been effective. The essence of THK and SK is regarded as the local wisdom which is truly a development of eco-tourism based the genuine of local culture in developing rural tourism where the rural itself is the origin of the culture with its local wisdom not in urban or international resorts.
\end{abstract}

2455-8028 ${ }^{\circledR}$ Copyright 2019. The Author. This is an open-access article under the CC BY-SA license (https://creativecommons.org/licenses/by-sa/4.0/) All rights reserved.

\section{Author correspondence:}

Ni Nyoman Sri Astuti,

Politeknik Negeri Bali. Jalan Kampus Bukit Jimbaran, Badung, Bali, Indonesia

Email address: nyomansriastuti@pnb.ac.id

\footnotetext{
a Politeknik Negeri Bali, Denpasar, Indonesia

${ }^{\mathrm{b}}$ Politeknik Negeri Bali, Denpasar, Indonesia

${ }^{c}$ Politeknik Negeri Bali, Denpasar, Indonesia
} 


\section{Introduction}

As a world-popular tourist destination, Bali exists amid the diversity of local community which is spread out in 17,508 islands in Indonesia. Even though it has wrestled many years in tourism development, the island is still remaining in beauty and harmony. Therefore, some awards have been achieved as it is implemented the values of local wisdom such as Tri Hita karana (THK) and Sad Kerthi (SK). These two concepts of the social and natural environment based on Balinese cosmological philosophy are regarded as the local wisdom that keeps Bali in balance. THK is an underlying philosophy which is basically deal with harmony and balance between religious, social, and environment (Windia \& Ratna Komala Dewi, 2007; Pitana, 2010; Purana, 2016; Ardika, 2017; Mudana et al., 2018; Ginaya, 2018, Dewi et al., 2018). This concept of harmonious life that causes happiness is regarded as the universal proposal of "sustainability" associating economy, society and environment, but fundamentally based on a Western concept of nature - defined by its externality from humanity - and society - based on an ideal of individualism and equality (Pickel-Chevalier \& Budarma, 2016). Pickel further states that if both proclaim a desire to create a balance between mankind and "nature", whether they have the same meaning and in order to find this relationship, it is suggested at first to go back to the historical relationship between Balinese society and sustainable development issues, which date from 1987. Then a study will be conducted in more detail the specificities of the Balinese relationship with the environment through the local paradigm of THK.

Budarma \& Suarta (2018) states that THK conception and its co-trilogy approaches to nature manifested in six more practical devotion, termed as Sad Kertih, of a human being into their environment at large. Sad Kertih (SK) can be defined as six types of ceremonies aimed at preserving the harmony of nature and its contents or six concepts in preserving the environment (Wiana, 2004, 2018). Wiana further states that the concept of Sad Kertih is a Hindu teaching in Bali which can be traced to its source in the Balinese Purana or lontar in which this universe including humans according to the Vedas consists of elements of the Panca Maha Butha or five elements that are composed the universe. The effort to maintain the five elements in Panca Maha Butha was carried out through the preaching of SK, such as Atman Kertih or the soul purification, Samudra Kertih or purification for preserving the sea and ocean as well as their biotas living inside, Wana Kertih or purification for conserving flora and fauna, Danu Kertih or purification for preserving the lake and river as the source of fresh water, Jagat Kertih or earth preservation, Jana Kertih or maintaining harmonious social relationship. According to Puspawati (online) and Rahardini (2017), Sad Kertih is a concept of environmental preservation in the teachings of Hinduism. But implicitly, this concept is integrated into teaching ways to preserve water because water is the most purified element in the teachings of Hinduism.

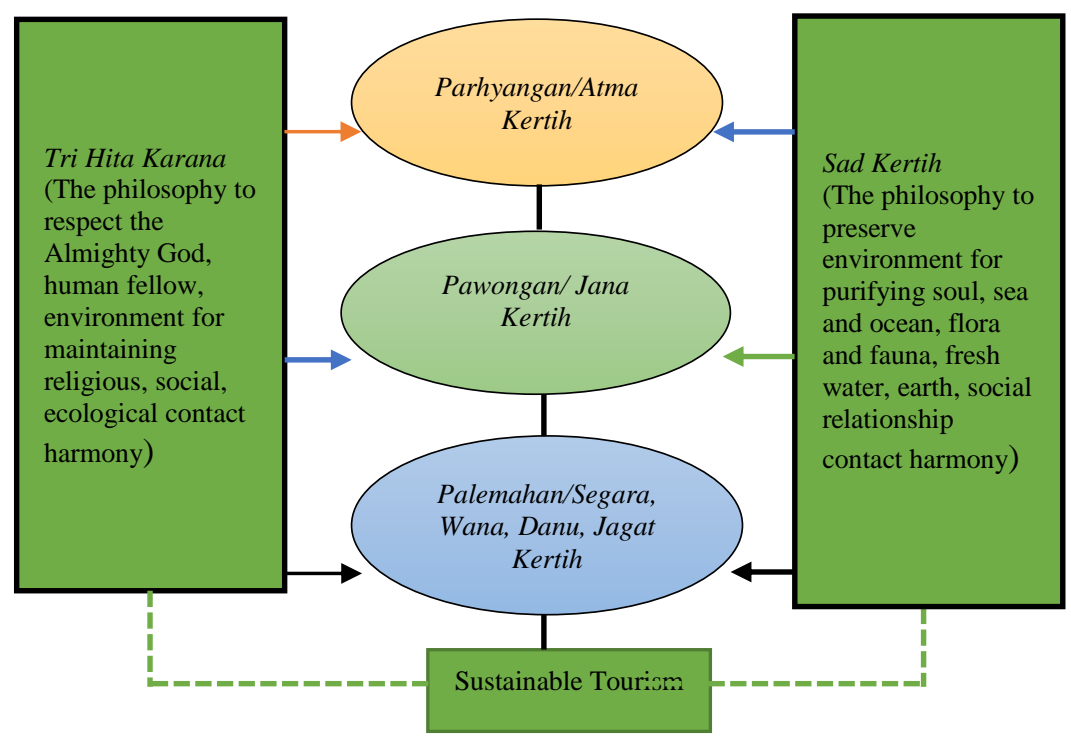

Figure 1. The philosophical concept of THK and SK

Astuti, N. N. S., Ginaya, G., \& Susyarini, N. P. W. A. (2018). Designing Bali tourism model through the implementation of tri hita karana and sad kertih values. International Journal of Linguistics, Literature and Culture, 5(1), 12-23. https://doi.org/10.21744/ijllc.v5n1.461 
However, when the tourism development nowadays it is merely focused on the economic growth, tourists who have high expectation on cultural uniqueness will get more and more difficult to grasp the uniqueness about Bali itself. As a result, the Bali tourism development does not only contribute to the regional and national economic growth but also it gives consequences towards the ecological and cultural Balinese community. Therefore, the design of tourism development tends to show wide gaps whenever faces the external strong current of information as the implication of the digital era. This situation brings people to the globalization era currently which is identical to an era of competition in every life aspect or sector, especially in the economic business sector including the tourism business industry. This can occur due to a significant increase in the number of tourist facilities, such as accommodation, transportation, souvenir shops, and tourists' attraction. For example, in 2006 it was recorded that the number of hotels was only 147star hotels and then increased to 281-star hotels in 2015, in other words, the number of star hotels has doubled in the last 9 years (BPS Provinsi Bali, 2015). However, this boosting quantity was not followed by an increasing number of room occupancy and the average guests' length of stay in the aforementioned star hotels. Consequently, it has created competition among star hotels themselves to increase their room occupancy. Additionally, the increased number of star hotels also followed by the lower category hotels like city hotels and villas.

Every endeavor to win a competition of the tourism tourist industry, it is required to have a uniqueness that is excellence in providing services for achieving guests' satisfaction in accordance with quality service dimension (Parasuraman et al., 1985; Kotler, 2002). However, unfortunately, the encounter between guests and hosts will not always successfully. Rosalina (2017) and aligned with Boniface (1995) stated that maintaining relationship among the hosts and the guests thus becomes inevitable and an important issue as the different cultural background could spark the cultural conflict, which could create notion that tourism is obviously related to the cultural differences and the wide gap among the hosts' and guests' cultures could elicit conflicts due to the actual scene of the tourist-host encounter. Additionally, Robinson \& Picard (2006) stated that close interaction between tourists and the locals generates conditions to dispel myths and stereotypes on both sides. Based on this situation, therefore, Reisinger \& Turner (2011) suggested that in order to diminish this conflict, it is the obligation for both hosts and guests to understand each other and keep the social interaction balance by seeing the adverse wisely that it could be minimized and even eliminated if tourists and hosts are aware of their cultural differences.

In reference to the above-mentioned problem, Bali where philosophies are immersed in every detail of its way of life, it is evident for Bali to improve the development of tourism by linking to its philosophy (Hofstede, 2001). Concerning the cultural tourism developed in the island of God, Bali with its local cultural concept has a distinguished character which can attract tourists to visit the island. This point of view is listed in Bali Provincial Regulation No. 2 the year 2012 concerning Balinese Cultural Tourism which states that Balinese culture as part of Indonesian culture is the main foundation of Bali's tourism development, which is able to operate tourism potential in the dynamics of local, national and global life. Additionally, there is part of the regulation which states about the local genius of Tri Hita Karana (THK) or three-genuine underlying philosophical concept of harmonious life, where the Balinese Hindu believe that this universe will be harmonious when humans can maintain good relations with God, fellow human beings, and the universe in a balanced way (Pitana, 2010; Gunarta, 2014; Mudana et al, 2018; Ginaya, 2018). Therefore, the three-folding concepts consisted of parhyangan, the vertical relation of humans to the almighty God, pawongan, the horizontal humans' relationship, and palemahan, the way how humans respect their environment where they live. This concept has been applied as a parameter in determining the consideration of green hotel category through THK Award. By applying the THK Award assessment indicator, it is required that every department should be able to give the local culture character in providing services to guests. In this case, every hotel department is expected to play an important role in providing quality assurance of services to guests. The concept of pawongan in THK derives Ttri Kaya Parisuda or three genuine human characters, manacika or positive thinking, wacika polite words, and kayika or good behavior. In addition, the horizontal relationship of human fellow derives another local wisdom which is termed as Catur Paramita or four genuine personal characters which are consisted of maitri or friendliness, karuna or courtesy, mudita or helpfulness, and upeksa or respectfulness (Astuti et al., 2018).

The ability of community in Bali in handling the acceleration of change, complexity, and miscellaneous development of tourism is still considered to be low and this matter can cause disorientation in giving the meaning of cultural tourism. The community capacity in managing tourism-based culture in Bali necessitates being empowered especially when the policy of norms and regulations that Bali is the truly locomotive and reflection of tourism in Indonesia. Therefore, tourism development oriented to mass tourism which tends to be an exploitation and commodification of the community potential either nature and culture should be shifted to the development of ecofriendly tourism based on the THK and SK values so that it will be gained the philosophy of justice and welfare for the whole community in the rural area. It needs to be emphasized here that the development of ecotourism-based 
culture and local wisdom should take place in rural areas because of the origin of the culture and local wisdom spring neither in urban areas nor in international-exclusive resorts but truly in rural areas.

\section{Materials and Methods}

This research was conducted by applying descriptive qualitative method. The sources and types of data are including both primary and secondary data. The primary data was obtained directly in the field through participant observation to 7 rural areas from various sub-districts of Bali Province and interview techniques (Denis, 2006; Ritchie et al., 2013). Whereas, the secondary data was collected through literature review technique (Bungin, 2001). The related informants, such as Front Office Managers and front office staff including receptionists, guest relation officers, guest services as well as guests in the house were selected based on purposive sampling technique. The additional information to complete the data which is considered still insufficient was done by using snowball sampling technique as one of the non-probability sampling techniques in qualitative research by looking for key informants in field research that helps researchers find other key informants or open access to respondents to be studied (Bungin, 2001). This sampling technique is applied for the purpose of examining those which are related to the local wisdom of Catur Paramita in developing cultural tourism of Bali which its soul spirit underlying principles is Hindu religion, such as priests, scholars of Hindu religion institute.

The data, subsequently, were analyzed with qualitative descriptive methods based on an inductive methodological paradigm that departs from specific principles general (Masun, 2005). Additionally, by applying descriptive analysis method, the data that has been collected in the form of implementing THK and SK by describing information obtained from triangulation data collection provided by stakeholders, namely by comparing data obtained from interviews with the stakeholders, observations made by researchers and documents related to the problem. So that later the results obtained can be tested for validity and can be described or explained in the discussion. The results of the study are presented in formal and informal methods. According to Sugiyono (2009), the method of informal presentation is to present the results of the analysis with a description or regular words, while the method of formal presentation is the formulation with signs and symbols. Hammond \& Welington(2012) states that the symbols or signs are used to present or formulate the results of the analysis so that the meanings of rules and concepts, inter-rule and concept relations, and the rules and concepts of peculiarities can be identified and understood the method of formal is informal presentation is to present the results of the analysis with a description or ordinary words.

\section{Results and Discussions}

This study concerns with analyzing the qualitative data from the answer of the research question from the whole observation, in-depth interview, and literature review of implementing THK and SK values in designing Bali tourism model. The research questions in this study were concerned about how THK and SK values are able to be a designed model of tourism development in rural areas in Bali. This tourism development model can be as an opportunity for diversifying Bali tourist attraction endeavor. Additionally, all the tourism potential possessed as the rural charms yet it is an unknown tourist attraction in Bali and it becomes an endeavor to pursue a diversifying place of interests in the island where tourists might visit the world-famous tourist destination. The endeavor requires a distinctive policy of rural ecotourism as micro business units under the principles of THK and SK values as local wisdom derived from the rural areas. The genuine values are the reflection of the traditional community that remains to possess the pride of selfentity and identity amid the threat of globalization effect. All of the aforementioned issues are discussed in this part.

\subsection{Rural Areas' Tourism as an alternate of Designing Bali Tourism Model}

Development of rural areas' tourism absolutely requires community participation, especially in the management of resources. Starting from the identification of problems faced by the rural areas' community, it is very urgent for the academician, the tourism experts, and practitioners to conduct community service to find solutions to the problems faced. Before conducting service activities, there should be a focused group discussion (FGD) on existing problems to discuss problems and find solutions according to real needs in the community. After conducting socialization and discussion then formulating targets and solutions as well as outcomes according to a mutual agreement in the FGD. The Faculty or Department of a university or college, for example, that conducts service activities in a rural area

Astuti, N. N. S., Ginaya, G., \& Susyarini, N. P. W. A. (2018). Designing Bali tourism model through the implementation of tri hita karana and sad kertih values. International Journal of Linguistics, Literature and Culture, 5(1), 12-23. https://doi.org/10.21744/ijllc.v5n1.461 
certainly has development plans in the fields of infrastructure, human resources, and management at the group of the community in the rural areas. A combination of methods and plans, the team of experts in the community of rural areas can formulate a relevant model in carrying out cultivation activities in the rural area. The tourism rural area development model can be used as a reference from the planning, implementation, and program evaluation phases which are arranged holistically from the development of the tourism village through training and assistance during the activities.

The development of a formulated tourism rural area should be as far as possible a representation of community participation in every aspect. Likewise, the expectations of the rural area community in developing tourism rural areas in accordance with the potential of the rural area in the future are (1) Development of rural area Pokdarwis or an organization of tourism awareness as much as possible involving the community as a concept of community-based tourism development (CBT) involving all components of community members actively involved in development rural area's tourism potential becomes a tourist destination; (2) CBT that emphasizes the economic side should also be based on THK and SK local wisdom or the balance of relations among human fellows to their Almighty God, fellows themselves in social interaction, and environment in the rural area's community in carrying out their lives as an effort to create a peaceful, harmonious and happy community life. These three harmonious relationships that lead to happiness will foster the feeling of "the paras-paros sarpanaya, sagulak-sagulik, salulung sabayantaka" or the appreciation of the rights of local communities and maintaining the preservation of the environment in the village of Sangkan Gunung; (3) the use of houses as tourist accommodation and or construction of homestays by recruiting local people as their employees; and (4) there are tourism villages as the development of the Pokdarwis itself which is an autonomous and independent institution formed by local communities under the responsibility of the official village and also involves traditional villages.

The community must be convinced that there is a guarantee that the involvement of all components of society can be involved and play an active role in the development of the tourism village with the aim of the village tourism development program running on the track record according to the needs of the community itself. Therefore, it can be formulated as follows. (1) development of tourism villages must be based on local wisdom that thrives in the midst of people's lives as supporters of a culture; (2) the local community becomes the center of development as an actor or subject of the entire development process. Thus, it is expected that community participation as a tourism potential owner will have motivation as an inner drive or drive that is purely from the conscience of the community itself as well as welfare of the rural area community; (3) the development of rural area tourism requires a solid partnership between the three main elements, namely the government, especially the Regency as struggled access to be obtained, private sector, and non-governmental organizations, where the rural area community becomes stakeholders of the cooperation; (4) the three stakeholders are in an equal position in carrying out cooperation and mutual respect; (5) an autonomous and independent management board needs to be formed, which interacts with each other, provides implementation feedback to correct itself at every level of the organization; (6) decisions and initiatives to meet the needs of rural communities are made in the rural area itself by local community leaders who have an identity and are recognized as participants in the decision-making process; and (7) the main focus of the development of rural area tourism is to strengthen the ability of the rural area community to direct and control the rural area's assets that are optimally utilized to meet the needs of their citizens. The implementation of relations between stakeholders is directed, the roles and responsibilities of each should be clear.

The implementation of relations between stakeholders is directed, the roles and responsibilities of each should be clear. The roles and authorities of each stakeholder are as follows. The Role and Authority of the Regency Government and hand in hand together with the community of institutions, namely the higher educational institution that conducts community service in the rural area, namely (1) fostering quality rural area products and packaging as elements of tourist memories; (2) arranging and conserving the physical environment of the area that is characteristic of tourist villages; (3) doing repairs / procurement of supporting infrastructure both concerning the tourism potential itself and in terms of waste management, especially plastic waste which is a scourge in the community not only to the people in the rural area but in all urban areas and villages in all of Bali including sanitation; (4) conducting community movements to realize the charm of the rural area; (5) making tourism information and facilities; (6) improve the quality of public spaces, access roads to tourism potential such as waterfalls, holy water for rituals and yoga, agri-business and rural area landscape to support Sapta Pesona or seven tourist enchantments; and (7) support for empowerment of Pokdarwis in the preservation of the tourism area environment both forest or plantation areas, waterfalls and holy water, and temples.

The role and authority of private investors, the elements of Higher Education, NGOs, and other tourism actors, namely (1) carry out integrated promotions between tourist managers to drive tourist visits between attractions; (2) 
making and marketing competitive tour packages that are affordable to tourists; (3) entrepreneurship training, individual skills training related to businesses in the field of tourism, such as foreign language training: English, Japanese, Russian, Mandarin, hospitality and tour guiding training, training to know the culture, and characteristics of domestic and foreign tourists; (4) development of joint business groups of the community; and (5) running a hospitality business especially homestays, restaurants, souvenirs, and various other facilities.

The role of the local community, namely (1) provides the most attractions while determining the quality of tourism products. Traditional management of agricultural or plantation land, traditional ceremonies, handicrafts from products such as virgin coconut oil (VCO) by utilizing coconut plantation crops to traditional weaving handicrafts and wood carvings and hygiene are some examples of roles that attract tourists; (2) cultural actors, for example, arts in the form of traditional dances that are developed on the creation of rural communities become one of the tourist attractions; and (3) providers of accommodation and tour guide services, provision of labor, typical food products, local handicrafts, local arts, and some typical attractions of the rural areas.

The Role and Authority of the Management Agency, namely (1) the management board as the main manager and director in protection, care, preservation in order to maintain its function as a cultural and natural heritage village; (2) make arrangements necessary for the development of rural area Tourism; (3) providing and operating all facilities to support business activities; (4) giving and revoking placement permits, stipulating requirements all commercial businesses in rural area Tourism; (5) determine and collect fees / levies and other levies for the utilization of available facilities and the results are entirely income from tourism management agencies in the rural area tourism; (6) carry out planning in the field of attraction / tourism product development, development of tourist facilities; (8) organizing in the field of institutional strengthening and development; (9) conduct a briefing to increase the competency of tourist management managers to be in line with the objective of developing a sustainable rural area tourism; and (10) conduct evaluation and supervision of tourism activities in order to achieve the sustainable development goals of rural area tourism.

Table 1

Method of designing rural area tourism development

\begin{tabular}{|c|c|c|c|}
\hline Data & Activity & Method & Rationale \\
\hline $\begin{array}{l}\text { Record the potential of } \\
\text { tourism to be developed }\end{array}$ & Website procurement & $\begin{array}{l}\text { Procurement of website in } \\
\text { English and other foreign } \\
\text { languages }\end{array}$ & $\begin{array}{l}\text { The website is } \\
\text { available for Pokdarwis }\end{array}$ \\
\hline $\begin{array}{l}\text { Development of supporting } \\
\text { infrastructure and facilities }\end{array}$ & $\begin{array}{l}\text { Developing rural } \\
\text { areas' Pokdarwis } \\
\text { become a tourist } \\
\text { village }\end{array}$ & $\begin{array}{l}\text { The material of the website is } \\
\text { collected and compiled together } \\
\text { between Pokdarwis teams and } \\
\text { personnel }\end{array}$ & $\begin{array}{l}\text { The website provides } \\
\text { access to information } \\
\text { about Pokdarwis to } \\
\text { market }\end{array}$ \\
\hline $\begin{array}{l}\text { Tourism product } \\
\text { development }\end{array}$ & $\begin{array}{l}\text { Product packaging / } \\
\text { standard prices in } \\
\text { brochures for CBT } \\
\text { socialization }\end{array}$ & $\begin{array}{l}\text { Pack products at prices } \\
\text { according to the market } \\
\text { demand }\end{array}$ & $\begin{array}{l}\text { The existence of } \\
\text { product information } \\
\text { and price structure, and } \\
\text { the availability of these } \\
\text { products at Pokdarwis }\end{array}$ \\
\hline $\begin{array}{l}\text { HR development and } \\
\text { management operations }\end{array}$ & $\begin{array}{l}\text { Procurement of } \\
\text { financial } \\
\text { management training }\end{array}$ & $\begin{array}{l}\text { The program was conducted } \\
\text { with a workshop }\end{array}$ & $\begin{array}{l}\text { Financial management } \\
\text { is an important aspect } \\
\text { management for } \\
\text { sustainable business }\end{array}$ \\
\hline $\begin{array}{l}\text { Development of production } \\
\text { facilities used by craftsmen }\end{array}$ & $\begin{array}{l}\text { Training } \\
\text { provision of welcome } \\
\text { drink and breakfast }\end{array}$ & $\begin{array}{l}\text { Half-day training in the form of } \\
\text { welcome drink and breakfast } \\
\text { supply workshop }\end{array}$ & $\begin{array}{l}\text { Both aspects are } \\
\text { essential, } \\
\text { welcome drink shows } \\
\text { hospitality, and } \\
\text { breakfast is an essential } \\
\text { element of eating - } \\
\text { drinking for guests. }\end{array}$ \\
\hline
\end{tabular}

Astuti, N. N. S., Ginaya, G., \& Susyarini, N. P. W. A. (2018). Designing Bali tourism model through the implementation of tri hita karana and sad kertih values. International Journal of Linguistics, Literature and Culture, 5(1), 12-23. https://doi.org/10.21744/ijllc.v5n1.461 


\begin{tabular}{llll}
\hline $\begin{array}{l}\text { Development of marketing } \\
\text { strategies }\end{array}$ & $\begin{array}{l}\text { Layout } \\
\text { parking/reception } \\
\text { area }\end{array}$ & $\begin{array}{l}\text { Arrangements are made with } \\
\text { Fixing the paving block and } \\
\text { planting trees for the fresh air }\end{array}$ & $\begin{array}{l}\text { Parking/Ticket } \\
\text { office/TIC of the rural } \\
\text { areas' tourism is the } \\
\text { first stop for tourists, it } \\
\text { can also function as a } \\
\text { reception area for } \\
\text { guests so it needs to be } \\
\text { displayed properly. }\end{array}$ \\
& &
\end{tabular}

\subsection{Tourism Potential of Rural Area Tourism}

Potential that might be developed in rural area tourist attraction is about the natural resources and natural beauty as well as art and culture. Based on observations that have been done, the potential that existed in several rural areas' tourism in 4 subdistricts of Bali Province, such as Belimbing village, Gunung Salak, Timpag in Tabanan Subdistrict, Sangkan Gunung, Tri Eka Buana in Karangasem, Wanagiri, Munduk villages in Buleleng, and Sala village in Bangli. Those villages represent rural areas which possess the treasure of potential to be developed as a tourist destination with their charms including the natural beauty where it is located at an altitude of approximately 800 until 2000 meters above sea level is surrounding by panoramic natural beauty with the background of Wide Lakes, valleys, mountains, rice terraces. It provides an individual value for the tourist especially for those who love nature and enjoy the local cultural experiences. The Natural beauty can be offered to the tourist for the potential value of a place to take pictures or even organize a pre-wedding photo shoot for bride and groom who want a background of the natural beauty for their pre-wedding theme. In addition, a purification ritual can be done from fresh spring water which in Bali the water is believed to have the power of healing as it is shown in figure 1.

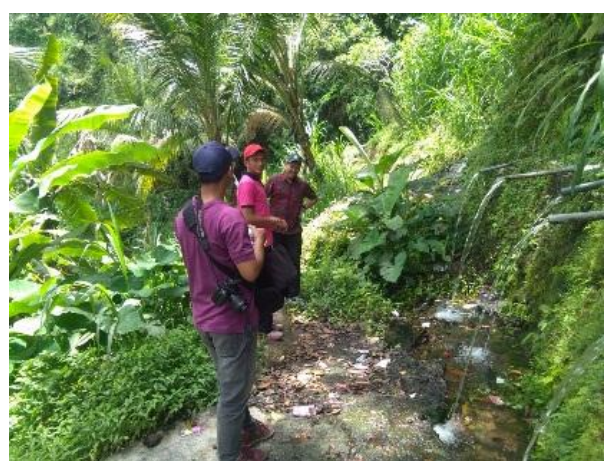

Figure 1. Spring Water Mumbul and Tunjung Kuning Sangkan Gunung Village

Visitors can also observe architecture of pura or a temple in a village as a place for worshipping of the rural area community and a place of melukat or purification ritual if the temple is built in beji or holy spring water like Pura Pecampuhan in Sala village in figure 2. In some occasions, there are temple festival or odalan which occurs in accordance with Balinese calendar either Sasih or lunar calendar it occurs annually or Pawukon every 210 days. 


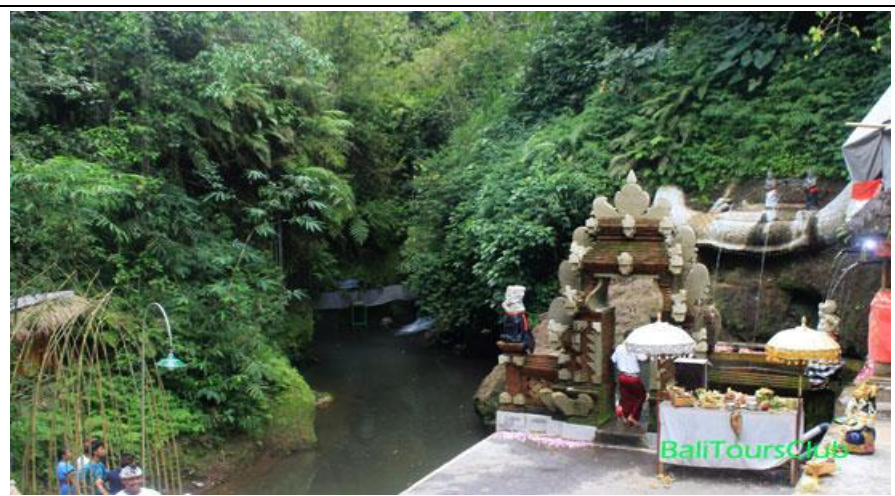

Figure 2. Pura Pecampuhan Sala

The natural beauty of hidden hill with a marvelous view where some leisure activities, such as treetop sling, jungle trekking, and hiking.

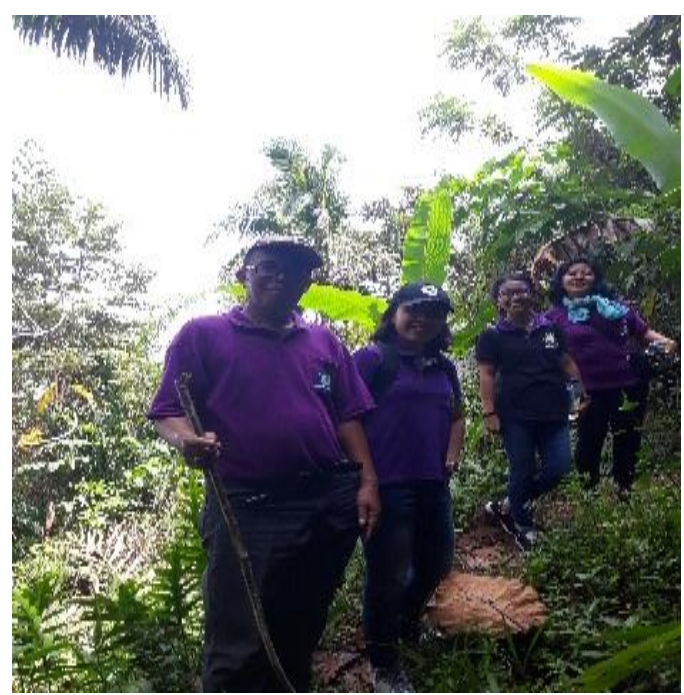

Figure 3. Jungle tracking in Tri Eka Bhuana Village

Additionally, is supplemented with coffee plantation, cocoa, local fruits, and spices. The local community can take the visitors to take a stroll along the plantation and show the process of making coffee powder from harvesting the coffee bean until it roasted in 2 and half hours and pounded to be powder and serve to the visitors to taste the local product of local coffee before they offer to get home for souvenir. In addition, the product of coffee luwak or the civet eating coffee bean and through the process of digestion the coffee beans are shitted then collected and processed to be an expensive coffee product as it contains enzyme of the nocturnal animal. Visitors may be wondering about the civet and it can be shown in the cage, there are plenty of them in Bali.

Astuti, N. N. S., Ginaya, G., \& Susyarini, N. P. W. A. (2018). Designing Bali tourism model through the implementation of tri hita karana and sad kertih values. International Journal of Linguistics, Literature and Culture, 5(1), 12-23. https://doi.org/10.21744/ijllc.v5n1.461 


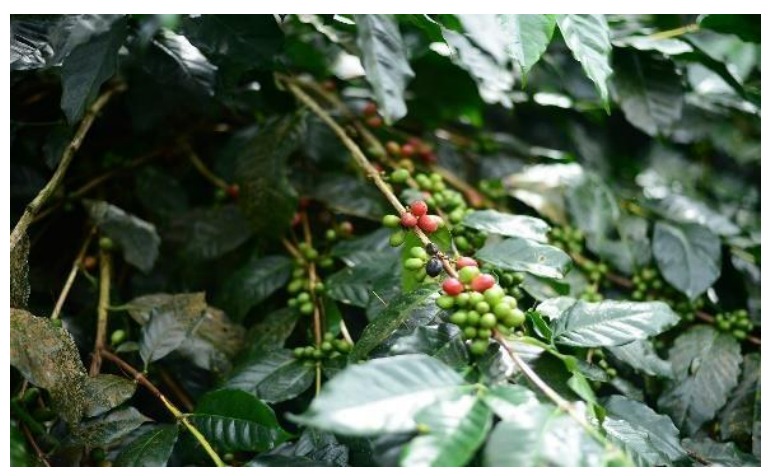

Figure 4. Coffee plantation in Wana Giri village

The house where the local people live can be utilized as a homestay for tourist with the concept of home sweet home in which the tourists can be the family member as they live in one compound.

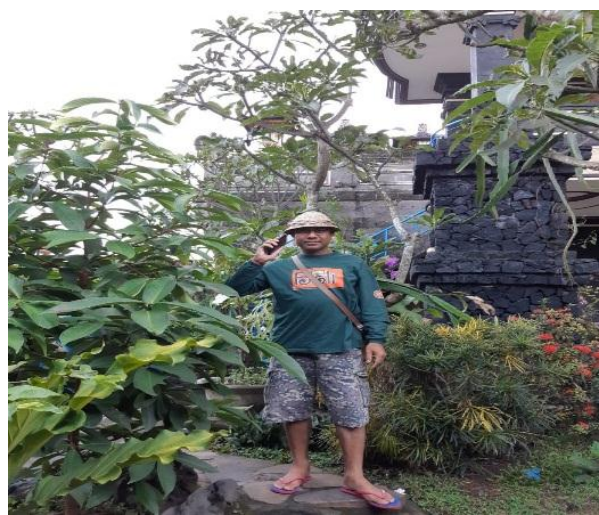

Figure 5. A local compound in Sangkan Gunung village utilized as a homestay for tourists

\section{Conclusion}

Based on the research result at the seven villages in the various subdistricts in Bali Province, it can be concluded that the existence of tourist attraction in every area of the subdistricts of Bali Province, so far, has provided a supply of pleasure and amusements for the tourists who spend their time for holidays in the island as a favorite tourist destination and well known among visitors not only the domestics but also overseas ones. Developing rural tourism that can offer the rural charms, with genuine tourism products either they are beautiful in nature, unique in culture, or challenge in the adventure as the blend of tranquillity and experience of home comfort has given the distinctive characters of diversifying tourist attraction endeavor. These purposive attempts of an active and proactive participant of the local inhabitant in the rural area were done as the designing of Bali tourism model through empowering the local communities of the rural areas by reinvention, conservation, and re-actualization of Tri Hita Karana and Sad Kertih as the local wisdom which springs in the rural areas.

Some suggestions could be shared which hopefully they could be a parameter reference for the purpose of the sustainable development of this diversified rural enchantment which involving the whole stakeholders. For example, for the elements of higher education institutions through community services and the local government side, they should facilitate the drawbacks that the rural area's community faced like providing facilities that make it easier for visitors to reach the tourist attraction as well as some facilities to ensure the visitor safety during visiting this tourist attraction. In addition, special training should be provided related to the development process of this attraction as well as foreign language courses to all staff who handle the guests as well as an internship photographer skill, a standard operating procedure in which all of them are an endeavor of ensuring the optimum services caused. Whereas, for local community side, the local community should raise their awareness and play an active role in developing the rural area 
tourist attraction while maintaining the sustainability of the object and also improve their competencies especially in foreign languages in order to be able to communicate effectively with the foreign visitors.

Conflict of interest statement and funding sources

The authors declared that they have no competing interest. The study was financed by Research Institution and Social Services.

Statement of authorship

The authors have a responsibility for the conception and design of the study. The authors have approved the final article.

\section{Acknowledgments}

We would like to express our gratitude to Politeknik Negeri Bali, specifically the Research Institution and Social Services for the funding of this research. For those who helped us to complete this research on time, we would also like to say thank you.

Astuti, N. N. S., Ginaya, G., \& Susyarini, N. P. W. A. (2018). Designing Bali tourism model through the implementation of tri hita karana and sad kertih values. International Journal of Linguistics, Literature and Culture, 5(1), 12-23. https://doi.org/10.21744/ijllc.v5n1.461 


\section{References}

Ardika, I. W. The Implementation of Tri Hita Karana on the World Heritage of Taman Ayun and Tirta Empul Temples as Tourist Attractions in Bali. E-Journal of Tourism, 85-93.

Astuti, NNS., Ginaya, G. \& Sadguna, IGAJ. (2018). A Hotel Front Desk Receptionist and Catur Paramita Values: A Study of Implementing Local Wisdom in Hospitality Industry. Proceedings of the 1st International Conference on Social Sciences (ICSS 2018). Atlantis Press.

Budarma, I. K., \& Suarta, K. (2017). The role of local value in global sustainable tourism development paradigm. the case of tourism in Bali. Journal of Business on Hospitality and Tourism, 2(1), 218-233.

Bungin, B. (2001). Metodologi penelitian sosial: format-format kuantitatif dan kualitatif.

Dennis, S. (2006). Understanding Qualitative Research and Ethnomethodology. The Australian Journal of Anthropology, 17(1), 121.

Dewi, I. G. A. A. O., Dewi, I. G. A. A. P., Kustina, K. T., \& Prena, G. D. (2018). Culture of tri hita karana on ease of use perception and use of accounting information system. International Journal of Social Sciences and Humanities, 2(2), 77-86. https://doi.org/10.29332/ijssh.v2n2.131

Ginaya, G. (2018). The Balinese calendar system: From its epistemological perspective to axiological practices. International Journal of Linguistics, Literature and Culture (IJLLC), 4(3), 24-37.

Gunarta, IM. (2014). Kearifan Bali: Bicara Melalui Tindakan. Penerbit Yayasan Kryasta Guna, Gianyar

Hammond, M., \& Wellington, J. (2012). Research methods: The key concepts. Routledge.

Hofstede, G. (2001). Culture's consequences: Comparing values, behaviors, institutions and organizations across nations. Sage publications.

Kotler, P. (2002). Manajemen Pemasaran Edisi Milenium. Jakarta: PT. Prenhallindo.

Mahsun, M. S. (2005). Metode penelitian bahasa: tahapan strategi, metode dan tekniknya. PT RajaGrafindo Persada.

Mudana, I. G., Suamba, I. B. P., Putra, I. M. A., \& Ardini, N. W. (2018, January). Practices of Bali Tourism Development, Threefolding, and Tri Hita Karana Local Knowledge in New Order Indonesia. In Journal of Physics: Conference Series(Vol. 953, No. 1, p. 012108). IOP Publishing. https://doi.org/10.1088/1742-6596/953/1/012108

Parasuraman, A., Zeithaml, V., \& Berry, L. (1985). A Conceptual Model of Service Quality and Its Implications for Future Research. Journal of Marketing, 49(4), 41-50. https://doi.org/10.2307/1251430

Pickel-Chevalier, S., \& Ketut, B. (2016). Towards sustainable tourism in Bali. A Western paradigm in the face of Balinese cultural uniqueness. Mondes du tourisme, (Hors-série).

Pitana, I. (2010). Tri Hita Karana-the local wisdom of the Balinese in managing development. In Trends and issues in Global Tourism 2010 (pp. 139-150). Springer, Berlin, Heidelberg. https://doi.org/10.1007/978-3-642-108297_18

Priscilla, B. (1995). Managing Quality Cultural Tourism.

PURANA, I. M. (2016). Pelaksanaan Tri Hita Karana Dalam Kehidupan Umat Hindu. Widya Accarya, 5(1).

Puspawati, SR. (Online). Sad Kertih Konsep Terpadu Pelestarian Air. Jurusan Brahma Widya STAHN Gde Pudja Mataram.

Rahardini, D. (2017). Pemanfaatan lahan "teba" dalam konservasi sumber daya air. Paduraksa: Jurnal Teknik Sipil Universitas Warmadewa, 3(2), 17-21.

Reisinger, Y., \& Turner, L. (2012). Cross-cultural behaviour in tourism. Routledge.

Ritchie, J., Lewis, J., Nicholls, C. M., \& Ormston, R. (Eds.). (2013). Qualitative research practice: A guide for social science students and researchers. sage.

Robinson, M., \& Picard, D. (2006). Tourism, culture and sustainable development. Unesco.

Rosalina, P. D. (2017). The Implementation of Hindu Philosophy "Tri Kaya Parisudha" for Sustainable Tourism in Munduk Village, North Bali. Jurnal Master Pariwisata (JUMPA).

Statistik, B. P. (2016). Nusa Tenggara Barat Dalam Angka 2016. Kabupaten Lombok Tengah: Badan Pusat Statistik. Sugiyono, M. P. P. (2009). Pendekatan Kualitatif. Kuantitatif dan R\&D, Jakarta: Alfabeta.

Wiana, IK. (2018). Implementasi Filosofi dan Konsepsi Pembangunan Bali (Bagian VII, Rubrik Wija Kasaur): Empat Fungsi Kebersamaan Universal, Pos Bali, Sunday, 20 May, p.1.

Wiana, K. (2004). Mengapa Bali Disebut Bali. Paramita.

Windia, W., \& Dewi, R. K. (2007). Analisis Bisnis yang Berlandaskan Tri Hita Karana. Universitas Udayana. 


\section{Biography of Authors}

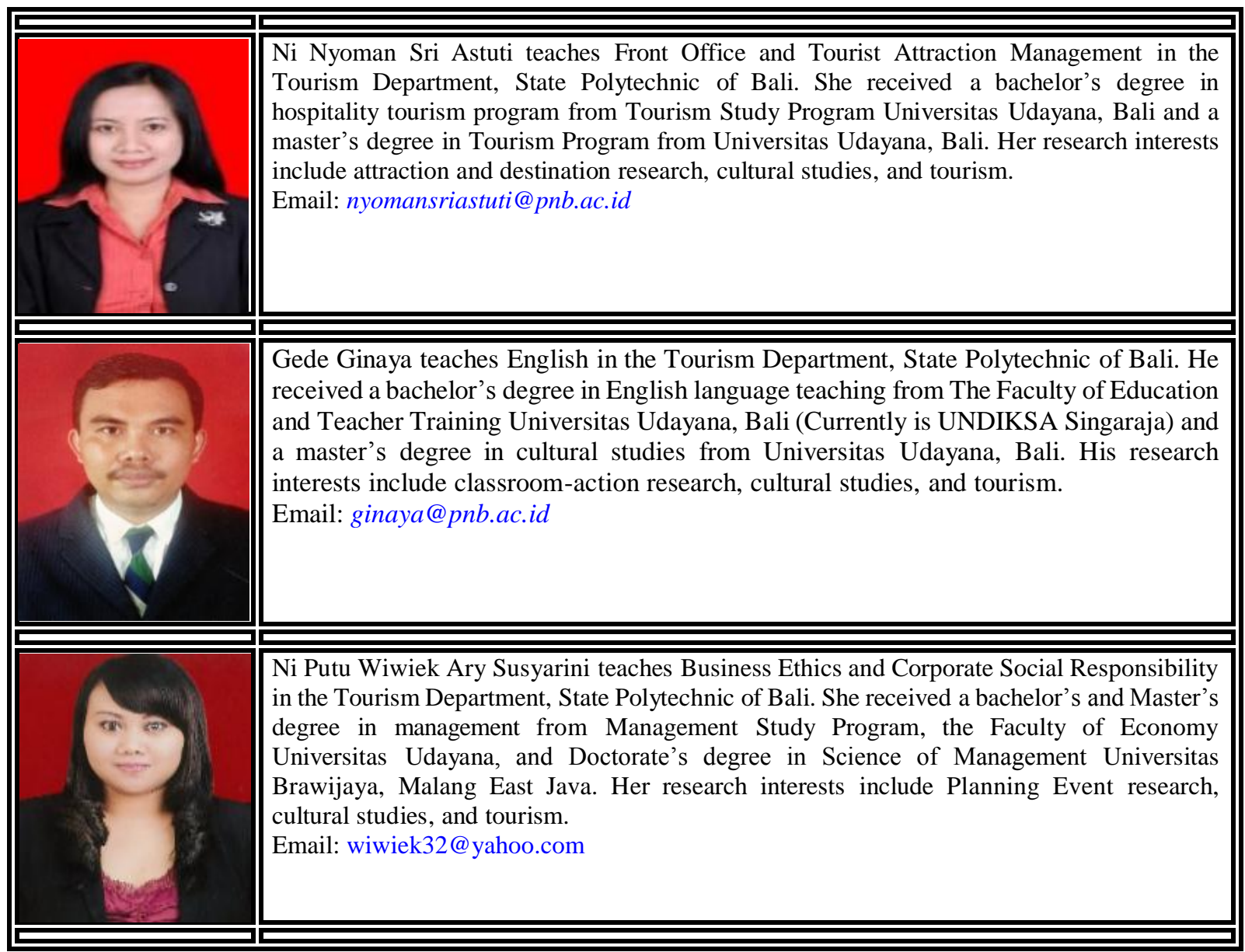

Astuti, N. N. S., Ginaya, G., \& Susyarini, N. P. W. A. (2018). Designing Bali tourism model through the implementation of tri hita karana and sad kertih values. International Journal of Linguistics, Literature and Culture, 5(1), 12-23. https://doi.org/10.21744/ijllc.v5n1.461 